\title{
PERBEDAAN MOTIVASI BERPRESTASI MAHASISWA SEMESTER VII-A JALUR SELEKSI PBUD DENGAN MAHASISWA SEMESTER VII- B JALUR SELEKSI LOKAL PADA PRODI PG PAUD FKIP UNIVERSITAS RIAU
}

\author{
Wusono Indarto ${ }^{*}$, dan Said Suhil Achmad ${ }^{1}$ \\ ${ }^{1}$ Fakultas Keguruan dan Ilmu Pendidikan Universitas Riau
}

\begin{abstract}
This research was intended to find out the disparity of motivation of achievement of the $7^{\text {th }}$ term student selected out through PBUD selection and ones picked out through local selection at the study program of PG PAUD in FKIP UR. This paper was a comparative research that it compared the indicator and variable to agroup of respondents. The data was collected by using an instrument in form of serveyor, in where the serveyor was developed from a variable of motivation with three indicators. Indicator I: the risk taker consisted of 12 discriptors; Indicator II: ones who needed feedback consisted of 8 discriptors; and Indicator III: ones who considered succes consisted of 8 discriptors. The number of all discriptors was 28 units. After being tested for the validity, 4 of them were invalid. The population of this research was 94 student who 42 of them were the students from PBUD selection and the other 52 were from the local selection. The sample of the research was 64 students, 30 of them were from PBUD selection and the other were from the local selection.

Based on the data collected, the score of motivation of achievement of the PBUD studends was 79.833 and percentage was 83.16\%. The number of percentage was "very high" after being matched with criterion. While the score of local selected students was 76.4112 oe the number in percent was $79.63 \%$ which was considered in the level of high. While in the hypothesis of search testing with computer calculation, it was showed that there was a disparity of the motivation of the students selected through PBUD selection to the ones picked out through local selection at the study program of PG PAUD in FKIP UR. Based on the calculation of $t_{\text {hitung, the result was }}$ 3.698327 higher than $t_{\text {tabel }}$ which was only $<3.698327>2.617$ in the level of significance 0.01 . Thus, Ho was rejected, which meant that there was a disparity of motivation on achievement of the $7^{\text {th }}$ term students of PBUD selection and the students of local selection.

Keyword: motivation of achievement
\end{abstract}

\section{PENDAHULUAN}

Minat para lulusan Sekolah Lanjutan Tingkat Atas untuk melanjutkan pendidikan ke FKIP Universitas Riau beberapa tahun terakhir menunjukkan kecenderungan yang terus meningkat. Masalah ini terkait dengan banyaknya kebijakan pemerintah yang berpihak pada dunia pendidikan. Kebijakan tersebut salah satu diantaranya adalah ketentuan undang-undang yang mewajibkan untuk mengalokasikan anggaran pendidikan minimal 20\%, baik pada level APBN, APBD baik provinsi maupun kabupaten. Hal ini juga berdampak pada peningkatan kesejahteraan tenaga pendidik dan tenaga kependidikan. 
Peningkatan kesejahteraan para pendidik tersebut nampaknya memicu minat para tamatan SLTA untuk meniti masa depannya pada jalur pendidikan. Kenyataan ini dapat dilihat dari para siswa yang berprestasi ikut dalam seleksi masuk peruguruan tinggi melalui jalur PBUD. Jalur ini disediadakan bagi para pelajar berprestasi yang masuk dalam peringkat 10 besar pada tingkat terakhir sewaktu mereka di bangku SLTA. Kebijakan ini juga diadopsi oleh FKIP untuk menjaring para calon guru yang berkualitas, sesuai dengan visi-misi FKIP Universitas Riau.

Para siswa yang diterima melalui jalur tersebut, mengindikasikan bahwa mereka sejak masih di tingkat sekolah telah menunjukkan dirinya sebagai siswa yang memiliki motivasi yang tinggi untuk meraih prestasi. Puncak dari raihan prestasi pada saat mereka di tingkat sekolah lanjutan atas adalah diterimanya para siswa tersebut melalui jalur PBUD. Akan tetapi setelah mereka diterima di perguruan tinggi, apakah motivasi berprestasi masih mereka miliki seperti sewaktu mereka masih di bangku sekolah.

Di sisi lain, perguruan tinggi dalam menjaring mahasiswa baru tidak cukup dilakukan melalui jalur PBUD. Akan tetapi masih ada pola seleksi penerimaan mahasiswa yang diterapkan oleh Direktorat Jenderal Pendidikan Tinggi Departemen Pendidikan dan Kebudayaan melalui Seleksi Nasional Masuk Perguruan Tinggi Negeri (SNPTN) Jalur PBUD. Pola ini juga sangat efektif untuk menjaring calon mahasiswa yang ingin masuk perguruan tinggi. Artinya para mahasiswa yang masuk melalui jalur tersebut secara kualitas tidak ada perbedaan yang jauh bila dibandingkan dengan para mahasiswa yang diterima melalui jalur seleksi lokal.

Akan tetapi kenyataan yang nampak dari hasil pengamatan peneliti, ternyata motivasi berprestasi mahasiswa yang diterima melalui jalur seleksi PBUD sebagian tidak memiliki perbedaan yang berarti dengan para mahasiswa yang diterima melalui jalur seleksi lokal. Hal ini dapat dilihat dari aspek keaktifan para mahasiswa dalam mengikuti perkuliahan, kepemilikan buku teks, ketepatan waktu dalam menyelesaikan tugas, dan frekuensi kunjungan ke perpustakaan. Kenyataan ini menarik untuk diteliti apakah memang benar di antara ke-dua kelompok mahasiswa tersebut tidak memiliki perbedaan motivasi prestasi dalam kegiatan perkuliahan. Kalau terdapat perbedaan, seberapa besar perbedaan motivasi berprestasi di antara kedua kelompok tersebut. Untuk mengkaji permasalahan di atas, peneliti akan mengkaji terlebih dahulu aspek teoritisnya berdasarkan pendapat para ahli tentang motivasi berprestasi.

\section{METODA PENELITIAN}

Penelitian yang akan dilaksanakan adalah penelitian komparatif. Penelitian komparatif adalah penelitian yang bersifat membandingkan antara dua kelompok untuk mengetahui ada tidaknya perbedaan diantara keduanya, Sugiyono (2007: 11). Sesuai dengan judul serta sifat penelitian yang akan 
dilakukan maka populasi dan sampel dalam penelitian ini adalah mahasiswa Semester VII yang masuknya melalui jalur PBUD dan seleksi lokal. Jumlah subyeknya untuk seleksi lokal 52 orang mahasiswa dan seleksi PBUD 42 orang mahasiswa. Dari kedua kelompok tersebut diperoleh sampel sebesar 64 orang dimana setiap kelompoknya diambil dengan rumus Slovin sebagai berikut:

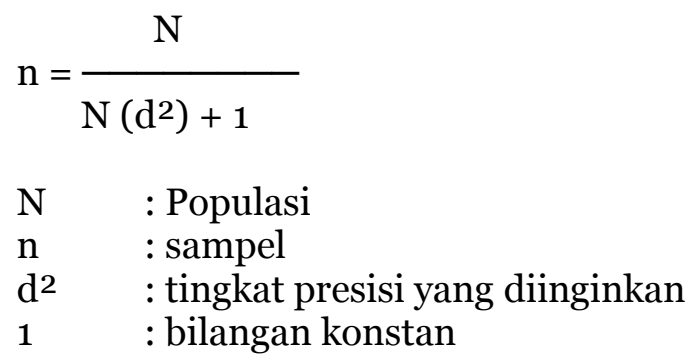

Sampel kelompok:

1. $\mathrm{n}=\frac{5^{2}}{5^{2\left(0.1^{2}\right)+1}}=\frac{5^{2}}{52\left(0.1^{2}\right)+1}=\frac{5^{2}}{52(0.01)+1}$

$$
\mathrm{N}=\frac{5^{2}}{0.52+1}=\frac{5^{2}}{1.52}=34.21=34
$$

2. $\mathrm{n}=\frac{42}{42(0.01)+1}=\frac{42}{0.42+1}=\frac{42}{1.42}=29.57=30$

Teknik pengumpulan data untuk penelitian ini dilakukan dengan teknik angket. Angket disusun berdasarkan variabel motivasi berprestasi yang terdiri dari tiga indikator yaitu: (1). suka mengambil resiko; (2). memerlukan umpan balik yang segera; (3). memperhitungkan keberhasilan. Dari ke-tiga indikator tersebut dapat dijabarkan menjadi 28 diskriptor. Setelah dilakukan uji coba, ternyata dari 28 diskriptor tersebut setelah dilakukan uji validitas terdapat 4 diskriptor yang tidak valid. Sehingga instrumen yang digunakan untuk pengumpulan data hanya terdiri dari 24 diskriptor.

Setelah data terkumpul, sebelum dilakukan analisis terlebih dahulu data tersebut diuji homogenitasnya. Dari hasil perhitungan komputer, ternyata data yang terkumpul bersifat homogen, sehingga data tersebut dapat dilakukan uji beda (uji t). Rumus yang digunakan untuk pengujian karena antara kelompok I dan kelompok II tidak sama $(\mathrm{n} 1 \neq \mathrm{n} 2)$ dan variansinya homogen untuk uji $t$ digunakan rumus: 


$$
\mathrm{t}=\frac{\bar{\chi}_{1}-\bar{\chi}_{2}}{\sqrt{\left\{\frac{\left.\underline{\mathrm{n}}_{1}-1\right) \mathrm{S}_{1}{ }^{2}+\left(\mathrm{n}_{2}-1\right) \mathrm{S}_{2}}{\mathrm{n}_{1}+\mathrm{n}_{2}-2}\right\}}\left(\underline{\underline{1}+\underline{1})} \mathrm{n}_{1} \mathrm{n}_{2}\right.}
$$

Dengan derajat kebebasan $(\mathrm{dk})=\mathrm{n}_{1}+\mathrm{n}_{2}-2$

\section{HASIL PENELITIAN}

\section{Deskripsi Data Penelitian}

Sesuai dengan variabel penelitian, maka data yang diperoleh adalah data mengenai Perbedaan motivasi berprestasi Mahasiswa PG PAUD Semester VII-A jalur Seleksi PBUD dan Mahasiswa PG PAUD Semester VII-B jalur Seleksi lokal/mandairi pada FKIP Universitas Riau. Data diperoleh dari instrumen angket motivasi berprestasi dengan indikator suka mengambil resiko yang moderat (moderate risk) terdiri dari 12 diskriptor, memerlukan umpan balik yang segera terdiri dari 8 diskriptor, dan memperhitungkan keberhasilan terdiri dari 8 diskriptor. Jumlah item seluruhnya sebelum dilakukan uji coba instrumen sebanyak 28 diskriptor.

Setelah dilakukan uji coba ternyata terdapat diskriptor yang tidak valid, yaitu pada indikator 1 (satu) pada butir nomor 1, pada indikator 2 (dua) pada butir nomor 15 dan 16, dan pada indikator 3 (tiga) pada butir nomor 28. Keempat butir tersebut setelah dilakukan uji validitas, skornya dibawah nilai kritis yang telah ditetapkan sehingga instrumen akhir yang dipakai untuk mengumpulkan data dari 3 indikator terdiri dari 24 diskriptor. Indikator 1 (satu) sebelas butir, indikator 2 (dua) enam butir, dan indikator 3 (tiga) sebanyak 7 butir.

Pilihan jawaban dalam angket terdiri dari 4 (empat) pilihan, yaitu Sangat Sering (SS) diberi bobot 4, Sering (SR) diberi bobot 3, Kadang-kadang (KD) diberi bobot 2, dan Tidak Pernah (TP) diberi bobot 1. Skor tertinggi memperoleh nilai $24 \times 4=96$ dan skor terendah $24 \times 1=24$ dengan rentang nilai antara 24 sampai 96. Berdasarkan skor nilai tersebut diolah untuk mendapatkan persentase yang selanjutnya ditentukan nilainya berdasarkan kriteria yang dikemukakan oleh Tuckman (1978: 285) sebagai berikut:

$$
\begin{array}{ll}
81-100 & : \text { sangat tinggi } \\
61-80 & : \text { tinggi } \\
41-60 & : \text { sedang } \\
21-40 & : \text { rendah } \\
00-20 & : \text { sangat rendah }
\end{array}
$$




\section{Motivasi Berprestasi Mahasiswa PG PAUD FKIP Universitas Riau}

a. Jalur Seleksi PBUD

Berdasarkan hasil tabulasi pengolahan data, diperoleh gambaran tentang motivasi berprestasi kelompok mahasiswa Semester VII-A jalur seleksi PBUD dengan 24 diskriptor dengan indikator I suka mengambil resiko, indikator II memerlukan umpan balik yang segera, dan indikator III Memperhitungkan keberhasilan, diperoleh hasil seperti yang tersaji dalam Tabel 3 berikut ini.

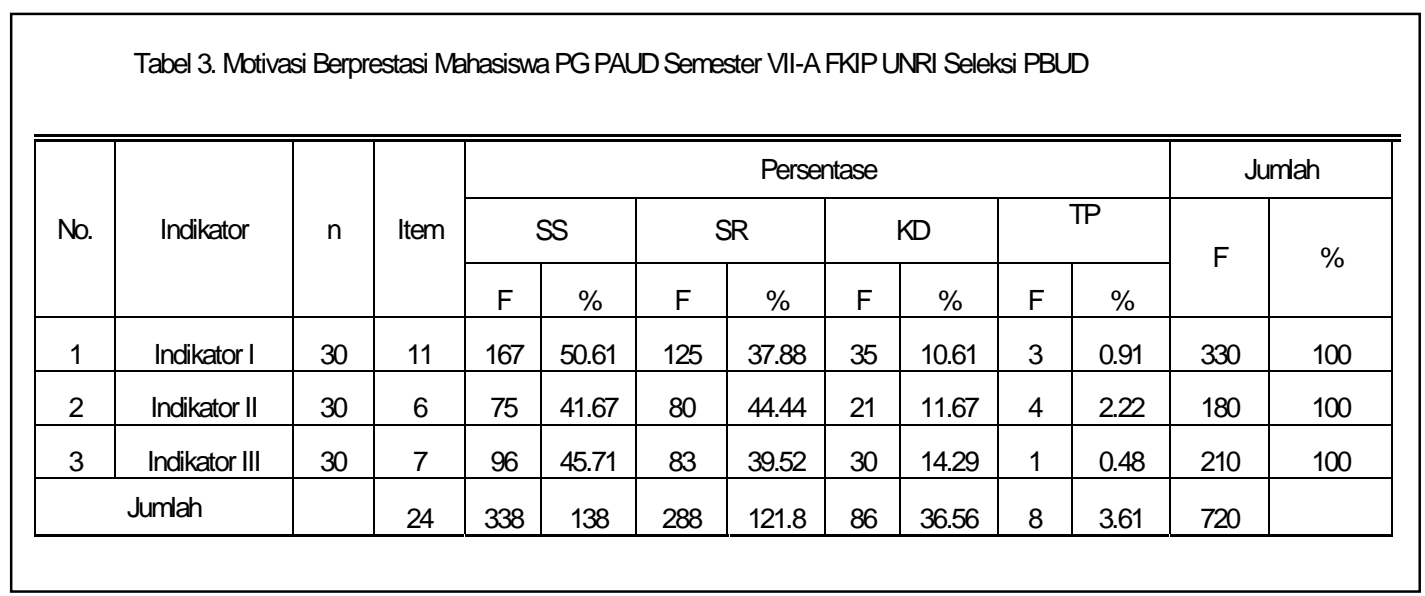

Pada indikator I ada 11 diskriptor dengan perolehan skor Sangat Sering (SS) sebesar 167 dengan persentase 50.61\%, Sering (SR) memperoleh skor 125 dengan persentase 37.88, Kadang-kadabg (KD) memperoleh skor 35 dengan persentase 10.61, dan Tidak Pernah (TP) memperoleh skor 3 dengan persentase 0.91 .

Pada indikator II ada 6 diskriptor dengan perolehan skor SS sebesar 75 dengan persentase $41.67 \%$, SR memperoleh skor 80 dengan persentase $44.44 \%$, KD memperoleh skor 21 dengan persentase 11.67\%, dan TP memperoleh skor 4 dengan persentase $2.22 \%$

Untuk indikator III ada 7 diskriptor dengan peroleh skor SS sebesar 96 dengan persentase $45.71 \%$, SR memperoleh skor 83 dengan persentase $39.52 \%$, KD memperoleh skor 30 dengan persentase 14.29\%, dan TP memperoleh skor 1 dengan persentase sebesar $0.48 \%$. Untuk memudahkan pembaca memahami sebaran data di atas, berikut ini akan digambarkan data tersebut dalam bentuk histogram. 


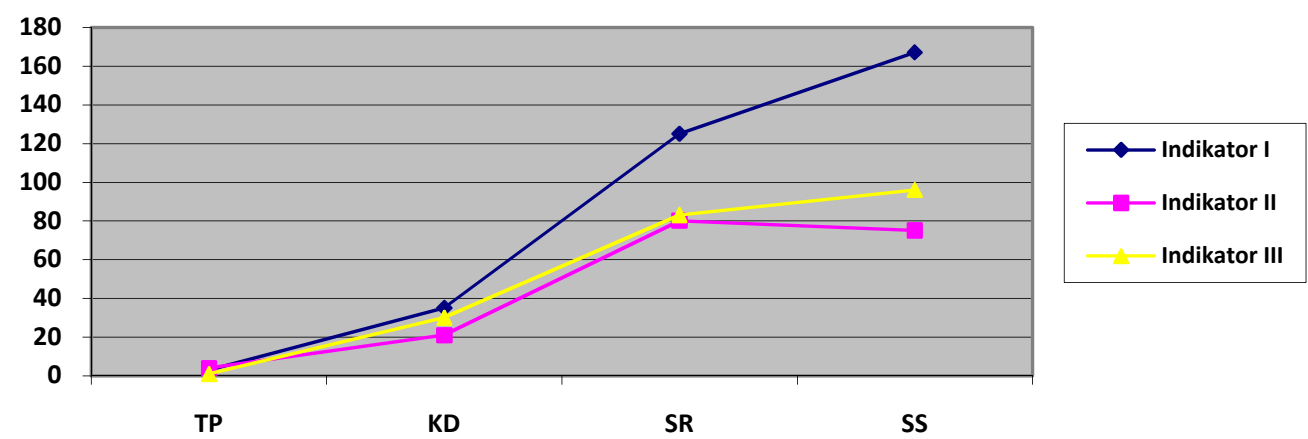

Gambar 1. Histogram Motivasi Berprestasi Mahasiswa Semester VII-A PG PAUD FKIP Universitas Riau Jalur Seleksi PBUD

Gambaran umum tentang motivasi berprestasi mahasiswa jalur seleksi PBUD Semester VII berdasarkan hasil pengolahan komputer diperoleh skor rata-rata sebesar 79.83 dari skor maksimum 96 (untuk 24 diskriptor) dengan persentase sebesar $83.16 \%$. Hasil tersebut bila dikonsultasikan dengan kriteria hasil termasuk dalam kategori sangat tinggi.

b. Jalur Seleksi Lokal/Mandiri

Sedang hasil tabulasi pengolahan data untuk jalur seleksi lokal/madiri, dari 24 diskriptor diperoleh hasil sebagai berikut:

Tabel 3. Motivasi Berprestasi Mahasiswa PG PAUD Semester VII-B FKIP UNRI seleksi Lokal

\begin{tabular}{|c|c|c|c|c|c|c|c|c|c|c|c|c|c|}
\hline \multirow{3}{*}{ No. } & \multirow{3}{*}{ Indikator } & \multirow{3}{*}{$n$} & \multirow{3}{*}{ Item } & \multicolumn{8}{|c|}{ Persentase } & \multicolumn{2}{|c|}{ Jumlah } \\
\hline & & & & \multicolumn{2}{|c|}{ SS } & \multicolumn{2}{|c|}{ SR } & \multicolumn{2}{|c|}{$\mathrm{KD}$} & \multicolumn{2}{|c|}{ TP } & \multirow{2}{*}{$F$} & \multirow{2}{*}{$\%$} \\
\hline & & & & $\mathrm{F}$ & $\%$ & $\mathrm{~F}$ & $\%$ & $\mathrm{~F}$ & $\%$ & $\mathrm{~F}$ & $\%$ & & \\
\hline 1 & Indikator I & 34 & 11 & 139 & 37.17 & 188 & 50.27 & 40 & 10.7 & 7 & 1.87 & 374 & 100 \\
\hline 2 & Indikator II & 34 & 6 & 71 & 34.63 & 105 & 51.22 & 27 & 13.17 & 1 & 0.49 & 205 & 100 \\
\hline 3 & Indikator III & 34 & 7 & 80 & 33.61 & 108 & 45.38 & 44 & 18.49 & 6 & 2.52 & 238 & 100 \\
\hline & Jumlah & & 24 & 290 & 35.54 & 401 & 49.14 & 111 & 13.6 & 14 & 1.72 & 816 & \\
\hline
\end{tabular}

Pada indikator I ada 11 diskriptor dengan perolehan skor Sangat Sering (SS) sebesar 139 dengan persentase 37.166\%, Sering (SR) memperoleh skor 188 dengan persentase 50.267\%, Kadang-kadabg (KD) memperoleh skor 40 dengan persentase 10.695\%, dan Tidak Pernah (TP) memperoleh skor 7 dengan persentase $1.872 \%$.

Pada indikator II ada 6 diskriptor dengan perolehan skor SS sebesar 71 dengan persentase 34.634\%, SR memperoleh skor 105 dengan persentase 51.22\%, KD memperoleh skor 28 dengan persentase 13.659\%, dan TP memperoleh skor 1 dengan persentase $0.488 \%$. 
Untuk indikator III ada 7 diskriptor dengan peroleh skor SS sebesar 80 dengan persentase 33.613\%, SR memperoleh skor 108 dengan persentase 45.378\%, KD memperoleh skor 44 dengan persentase $18.487 \%$, dan TP memperoleh skor 6 dengan persentase sebesar 2.521\%. Untuk memudahkan pembaca memahami sebaran data di atas, berikut ini akan digambarkan data tersebut dalam bentuk histogram.

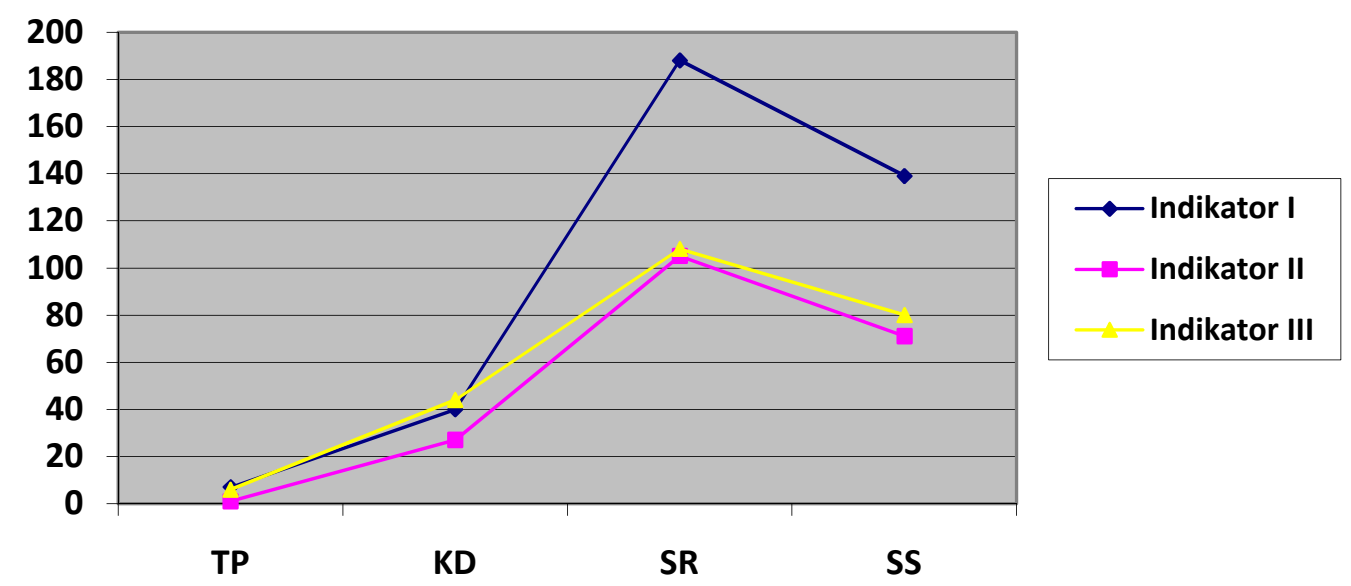

\section{Gambar 2. Histogram Motivasi Berprestasi Mahasiswa Semester VII_B PG PAUD FKIP Universitas Riau Jalur Seleksi PBUD}

Sedang tentang motivasi berprestasi mahasiswa PG PAUD FKIP jalur seleksi lokal/mandiri Semester VII berdasarkan hasil pengolahan komputer diperoleh skor rata-rata sebesar 76.44 dari skor maksimum 96 (untuk 24 diskriptor) dengan persentase sebesar 79.63\%. Hasil tersebut bila dikonsultasikan dengan kriteria hasil termasuk dalam kategori tinggi.

\section{Pengujian Hipotesis}

Berdasarkan hasil pengolahan data dengan menggunkan uji $t$ atau $t_{\text {test, }}$, didapat hasil perhitungan dengan langkah-langkah sebagai berikut:

Langkah perhitungan:

1. Merumuskan hipotesis

Ho $=$ Tidak terdapat perbedaan motivasi berprestasi antara mahasiswa Semester VI-A jalur seleksi PBUD dengan mahasiswa Semester VI-B jalur seleksi lokal pada Prodi PG PAUD FKIP Universitas Ria.

$\mathrm{Hi}=$ Terdapat perbedaan motivasi berprestasi antara mahasiswa Semester VII-A jalur seleksi PBUD dengan mahasiswa Semester VII-B jalur seleksi lokal pada Prodi PG PAUD FKIP Universitas Ria.

2. Melakukan Uji Homogenitas 
Sebelum dilakukan perhitungan untuk mencari perbedaan motivasi berprestasi antara mahasiswa Semester VII-A jalur seleksi PBUD dengan mahasiswa Semester VII-B jalur seleksi lokal pada Prodi PG PAUD FKIP Universitas Ria, data yang telah ditabulasi harus dilakukan uji homogenitas terlebih dahulu. Untuk melakukan uji homogenitas tersebut, mengacu pada pendapat Sugiyono (2007: 231) bahwa Jika jumlah sampel tidak sama $(\mathrm{n} 1 \neq \mathrm{n} 2)$ maka rumus yang digunakan untuk pengujian adalah sebagai berikut:

$$
\mathrm{F}=\frac{\text { Varian terbesar }}{\text { Varian terkecil }}
$$

Berdasarkan hasil tabulasi data dan perhitungan komputer Varian terbesar adalah 19.2557 berasal dari kelompok mahasiswa Semester VII-A jalur seleksi PBUD dan varian terkecil 9.86197 berasal dari kelompok mahasiswa Semester VII-B jalur seleksi lokal.

Berdasarkan data tersebut, maka hitungan uji $\mathrm{F} \mathrm{F}_{\text {hitung }} 1.9525206>$ dari $\mathrm{F}_{\text {tabel }}$ 1.8000 maka data tersebut berarti homogen. Berdasarkan uji tersebut data yang terkumpul selanjutnya dapat dilakukan Uji t ( $\mathrm{t}_{\text {hitung }}$ )

3. Melakukan Perhitungan untuk Uji t ( $\left.t_{\text {hitung }}\right)$.

Untuk melakukan Uji t rumus yang digunakan adalah sebagai berikut:

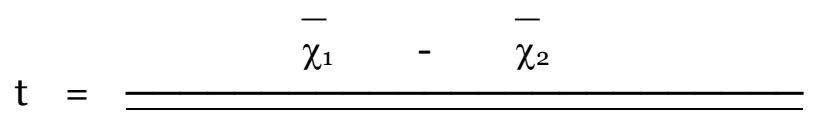

$$
\begin{aligned}
& \sqrt{ }\left\{\left(\underline{\mathrm{n}}_{1}-1\right) \mathrm{S}_{1}{ }^{2}+\left(\mathrm{n}_{2}-1\right) \mathrm{S}_{2} 2\right\}(\underline{1}+\underline{1}) \\
& \begin{array}{lll}
\mathrm{n}_{1}+\mathrm{n}_{2}-2 & \mathrm{n}_{1} & \mathrm{n}_{2}
\end{array} \\
& 79.833-76.4412 \\
& =\frac{79.833-76.4412}{\frac{\sqrt{\{(30-1) 19.2557+(34-1) 9.86197\}}}{(30+34)-2}(1+1)} 30 \quad 34
\end{aligned}
$$

$$
=3.698327
$$

$\mathrm{Df}=(\mathrm{n} 1+\mathrm{n} 2)-2=(30+34)-2=62$. Apabila dikonsultasikan dengan tabel nilai $t$ ternyata tidak dijumpai angka 62. Karena itu digunakan dk yang terdekat yaitu angka 6o, yaitu dk sebesar 2.660 untuk taraf signifikansi o.o1. Berdasarkan perhitungan di atas hasil $t_{\text {hitung }}$ diperoleh hasil sebesar 3.698327, lebih besar dari $t_{\text {tabel }}$ yakni $2.660<3.698327>2.617$ (Sugiyono: 368), sehingga Ho ditolak artinya terdapat perbedaan motivasi berprestasi antara mahasiswa 
semester VII-A PG PAUD Jalur Seleksi PBUD dengan mahasiswa semester VII-B PG PAUD Jalur Seleksi lokal/mandiri.

\section{PEMBAHASAN}

Berdasarkan data hasil perhitungan komputer skor perolehan mahasiswa mahasiswa Semester VII-A jalur seleksi PBUD, berdasarkan hitungan komputer diperoleh skor 79.83 dari skor maksimum 96 yang berasal dari 24 diskriptor. Apabila skor tersebut dihitung persentasenya diperoleh hasil 83.16\%, yang hasil tersebut dikonsultasikan dengan kriteria hasil termasuk kategori 'sangat tinggi'. Sementara skor yang diperoleh untuk kelompok Semester VII-B jalur seleksi lokal diperoleh angka sebesar 76.44 dari skor maksimum 96 yang berasal dari 24 diskriptor. Apabila skor kelompok jalur seleksi lokal dicari persentasenya diperoleh angka sebesar 79.63\%, dimana hasil tersebut bila dikonsultasikan dengan tabel kriteria hasil termasuk dalam kategori 'tinggi'.

Apabila dibandingkan skor dan persentasenya diperoleh gambaran, bahwa kelompok jalur seleksi PBUD lebih tinggi yaitu 83.16\% dengan kategori hasil sangat tinggi. Sementara kelompok jalur seleksi lokal persentasenya 79.63\% lebih rendah bila dibandingkan dengan persentase kelompok jalur seleksi PBUD. Hal ini menandakan, bahwa motivasi berprestasi jalur seleksi PBUD lebih tinggi dari jalur seleksi lokal. Artinya tradisi prestasi yang didapat pada waktu mereka pada jenjang SLTA berpengaruh positif terhadap motivasi berprestasi mereka pada saat di perguruan tinggi.

Sementara dari hasil pengujian hipotesis, diperoleh gambaran, bahwa hasil thitung diperoleh skor sebesar 3.698327, lebih besar dari tabel yakni $2.660<$ $3.698327>2.617$ (Sugiyono: 368), sehingga Ho ditolak artinya terdapat perbedaan motivasi berprestasi antara mahasiswa semester VII-A PG PAUD Jalur Seleksi PBUD dengan mahasiswa semester VII-B PG PAUD Jalur Seleksi lokal/mandiri. Hal ini sejalan dengan perolehan skor pada paragrap sebelumnya yang menggambarkan, bahwa motivasi berprestasi kelompok jalur seleksi PBUD lebih tinggi bila dibandingkan skor yang diperoleh jalur seleksi lokal.

Karena mahasiswa semester VII-A PG PAUD FKIP Universitas Riau seluruhnya diterima melalui jalur yang sama, sehingga pada kelompok tersebut bila dilihat dari aspek akademis relatif homogen. Hal ini bisa dimengerti, karena para mahasiswa tersebut pada saat di tingkat SLTA merupakan kelompok siswa yang berprestasi, sehingga budaya prestasi ini terbawa sewaktu mereka melanjutkan pendidikan pada jenjang yang lebih tinggi. Namun demikian tidak berarti, bahwa mahasiswa jalur seleksi mandiri/lokal memiliki disparitas motivasi berprestasi yang rendah. Karena dari kelompok jalur seleksi lokal/mandiri perolehan skor persentasenya tidak jauh berbeda bila dibandingkan dengan jalur seleksi PBUD. 


\section{PENUTUP}

Berdasarkan paparan permasalahan penelitian dan pengkajian kepustakaan yang relevan serta pengumpulan data dengan instrumen yang telah melalui uji validitas, secara umum diperoleh gambaran bahwa motivasi berprestasi mahasiswa semester VII-A PG PAUD FKIP Universitas Riau jalur seleksi PBUD lebih tinggi bila dibandingkan mahasiswa semester VII-B PG PAUD FKIP Universitas Riau jalur seleksi lokal. Hal ini sekaligus merupakan bukti bahwa Ho (Tidak terdapat perbedaan motivasi berprestasi antara mahasiswa semester VII-A PG PAUD FKIP Universitas Riau jalur seleksi PBUD dengan mahasiswa semester VII-B PG PAUD FKIP Universitas Riau jalur seleksi lokal) di tolak.

Atas dasar hasil pembuktian di atas, penelitian ini merekomen-dasikan bahwa pola seleksi PBUD untuk masuk perguruan tinggi masih dapat dipertahankan. Akan tetapi mengingat adanya sinyalemen rekayasa prestasi belajar siswa yang dilakukan oleh beberapa oknum guru di tingkat SLTA, agar siswa tertentu yang diinginkan dapat masuk perguruan tinggi melalui jalur tersebut, pihak perguruan tinggi perlu menerapkan persyaratan yang lebih ketat bagi para siswa yang ingin masuk melalui jalur tersebut. Hal ini sebagai upaya untuk menjaga mutu, bahwa para tamatan SLTA yang masuk perguruan tinggi melalui jalur PBUD secara kualitatif dapat dipertanggungjawabkan.

\section{Ucapan Terimakasih}

Pada bagian akhir tulisan ini, peneliti menyampaikan ucapan terimakasih kepada Bapak Dekan FKIP Universitas Riau atas perkenannya untuk mendanai kegiatan penelitian ini. Semoga penelitian ini dapat digunakan sebagai informasi dalam pengambilan kebijakan yang berkaitan dengan pola seleksi mahasiswa baru pada masa yang akan datang.

\section{Daftar Pustaka}

Bacal, Robert. 2001. Performance Management (terjemahan Surya Dharma dan Yanuar Irawan). Jakarta. Gramedia Pustaka Utama.

Gery Dessler. 1997. Personel Manajemen (Terjemahan Agus Dharma). Jakarta; Penerbit: Erlengga Hill.

Hadari Nawawi. 2005. Administrasi Pendidikan. Jakarta. Penerbit: Gramedia Pustaka Utama.

Hoy, Wayne K. dan Cecil G. Miskel. 1991. Educational Administration (Theory, Research and Practice). New York. McGraw

Keith Davis dan John W. Newstrom. 1996. Perilaku dalam Organisasi. Jakarta. Erlangga. 
Lindgren, Henry Clay. 1980. Educational Psychology in the Classroom. New York. Oxford University Press.

Melayu S.P. Hasibuan. 1996. Organisasi dan Motivasi. Bandung. Bumi Aksara.

Sugiyono. 2007. Metoda Penelitian Administrasi. Bandung. Penerbit: Alfabeta.

Suharsimi Arikunto. 2006. Prosedur Penelitian (Suatu Pendekatan Praktik). Jakarta. Penerbit: Rineka Cipta.

Wayne K. Hoy and Cecil G. Miskel. 1991. Educational Administration. New York. Mc. Graw Hill Inc.

Taylor, Shelley E. 1997. Social Psychology. New Jersey. Prantice-Hall, Inc.

T. Hani Handoko. 2001. Manajemen. YogyaKarta. BPFE UGM. 